\title{
FAMILY BEYOND BORDERS
}

\author{
Aleksandra Aleksandrova*
}

\begin{abstract}
The paper studies the way Lakoff's STATE IS A PERSON metaphor and Mussolf's family scenario are exploited in British and Bulgarian media texts. The models that are studied include marriage partners/ divorce, children-parents relations, misbehaving children, good children, poor relatives and stepmothers. The type of family relation used for presenting certain situation can change with a change in the political environment - for instance, a country can be presented as a marriage partner in one text, as a divorcee in another and as a (disobedient) child in a third text.
\end{abstract}

Key words: the state is a person metaphor, metaphor scenarios, family scenario

\section{Introduction.}

Member states are presented as children and the European Union is the family. In this study it was observed that countries with financial problems are called erring children, the European Union is their father, who cares for the children, but can also punish them. The following family scenarios are discussed: marriage partners/ divorce, misbehaving children, punishing the misbehaving children, good children, poor relatives and stepmothers.

\section{Previous research on the topic.}

The metaphor of the European family is widely exploited in the media (see Lakoff 2003; Musolff 2006; Ishpekova 2012). In Lakoff's view, a state is conceptualized as a person, "engaging in social relations within a world community" (Lakoff 1990). Musolff studies metaphors related to the EU organized in "scenarios". In his view, the thematic target (for instance, EU politics) is accessed through a source input for the metaphor complex (family/marriage/ concepts) and this is "characterized by the dominance of a few traditional, gender-coded stereotypes of family roles" (Musolff 2009: 1). Ishpekova (2012) uses Mussolf's theory of scenarios in studying the image of Bulgaria in The Financial Times and concludes that Bulgaria is presented as "the naughty child" in the EU family scenario.

\footnotetext{
* Assist. Professor PhD at Shumen University, Department of English Studies, Shumen, Bulgaria, e-mail: a.aleksandrova@shu.bg
} 


\section{Analysis.}

\subsection{Marriage partners}

When the UK voted for leaving the EU, a process referred to as Brexit, the event was compared to a divorce. Consequently, a list of notions from the domain of divorce were used in texts about Brexit: divorce settlement, divorce lawyers (The Daily Mail), divorce bill (The Financial Times). The event is characterized by verbs from the divorce domain, as in the following excerpt:

\section{U.K. files for $\boldsymbol{E} U$ divorce, triggering 2 years to Brexit}

Britain's EU envoy hand-delivers letter from Theresa May to EU Council president

The United Kingdom filed for divorce from the European Union on Wednesday, overturning four decades of integration with its neighbours, demolishing the notion that EU expansion is inevitable and shaking the foundations of a bloc that is facing challenges to its identity and its place in the world. (www.cbc.ca/ news, 29/03/2017)

In the headline, the source concept files for EU divorce is used to access the target notion to start a formal procedure for leaving the EU. In the subhead, the event is described in literal terms, while in the main text again the metaphorical expression is used.

\subsection{Children-parents.}

The children-parents model is found in texts about political relations between the EU and member counties. The EU and its institutions are presented as a strict parent, while member countries are the children, who need to be criticized, scolded or punished when they misbehave. In the next excerpt, the verb scold, which means to "criticize someone, especially a child" (www.ldoceonline.com) is used to stand for reporting EU countries' failure to fulfill their obligations:

\section{Commission scolds $E U$ countries for not paying into refugee fund}

Progress report looks at the EU-Turkey deal by the numbers.

Twelve countries have contributed nothing so far to the $€ 3$ billion EU-Turkey deal, according to a European Commission report published Wednesday. (www.politico.eu 21/04/2016)

The idea that a member state is a child is reinforced by the failure to fulfill a requirement being directly called disobedience, as in the following excerpt:

Varoufakis would resign as a minister, and would never again have to endure all-day meetings in Brussels and Luxembourg, listening to other European finance ministers scold Greece for its disobedience. (http://www.newyorker. com, 03/08/2015). 
The relation between the source domain concepts and the target domain concepts are presented in the table below:

\begin{tabular}{|l|l|}
\hline \multicolumn{1}{|c|}{ Source concept: } & \multicolumn{1}{c|}{ Target concept: } \\
\hline Scold & To state a failure in obligations \\
\hline Disobedience & A failure in obligations \\
\hline
\end{tabular}

The expression гълча, сгълчавам, meaning "to scold" is used in the Bulgarian press with the same metaphorical meaning:

ЕС сгълча Анкара за арестите на журналисти (http://www.sbj-bg.eu, 22/06/2016)

The EU scolded Ankara over journalists' arrests (http://www.sbj-bg.eu, 22/06/2016)

The EU, Brussels, and the European Commission are used interchangeably in such texts, as they form a metonymic chain with target notion one of the institutions in the EU. It is possible for one unit of the nominative chain to be found in the text's headline, another in the main text, then the first one to be repeated again. In all cases, however, all the units in the metonymic chain are used in the metaphoric concept "Strict parent", while the countries occupy the position of the misbehaving child. The verb "scold" can have different variations and degrees of meaning. While in some cases it is used to stand for criticism and stating a county's failure, there are cases in which it means directly to launch an infringement procedure. In the following excerpt, the metaphorical expression is in the headline, while in the main text the literal expression is used:

\section{Брюксел пак сгълча Унгария за медийния закон}

Европейската комисия не изключва възможността за предприемане на наказателна процедура срещу Унгария по повод новия медиен закон и спирането на Клуб радио. (http://sbj-bg.eu, 19/01/2012)

\section{Brussels scolded Hungary over media law again}

The European Commission does not rule out the possibility of launching an infringement procedure against Hungary because of the new media law and Klub radio termination. (http://sbj-bg.eu, 19/01/2012)

In some texts, the parent-children relation is expressed by explicitly calling member countries "children" and using adjectives like "misbehaving" and "infantilized". The word "child" is used as a synonym of immature behaviour. To emphasize on that meaning, the word "adult" is used later in the text of the following excerpt to stress the contrast: 
Greece is not a "misbehaving child", as Giles calls it. It is infantilised by its creditors' unwillingness to release it from debtors' prison, leaving it dependent on them for conditional liquidity. As adults, Greeks need to regain control over their destiny. Let them then hold the Syriza government accountable for its decisions at the next election. (http://www.philippelegrain. com/a-response-to-chris-giles-on-greece/, 03/07/3015)

Misbehaving children can be not only scolded, but also punished by their parents. This scenario is used with the family metaphor in texts about relations between member states and organizations of the EU. In such type of metaphors, the units of the metonymic chain representing "the child" are used interchangeably - the country and the head of the country are used synonymously, as is evident in the next excerpt:

\section{Tsipras has earned his punishment}

In another act of solidarity, creditors have made it perfectly clear that further debt relief will be on offer once Greece implements the lending conditions to which it says it agrees. This is a perfectly sensible attempt to reward good behaviour on the principle that you do not give treats to a misbehaving child. ... The longer Syriza pulls fresh stunts, the more pain Greece will suffer with the danger that Mr Tsipras will lead it out of both the eurozone and the EU. (www.ft.com, 02/07/2015) .

The relation between the source concept and the target concept is represented in the table below:

\begin{tabular}{|l|l|}
\hline \multicolumn{1}{|c|}{ Source concept } & \multicolumn{1}{c|}{ Target concept } \\
\hline Punishment & Greece's economic crisis \\
\hline Misbehaving child & $\begin{array}{l}\text { A country that does not implement the } \\
\text { lending conditions }\end{array}$ \\
\hline $\begin{array}{l}\text { Give a treat to a misbehaving } \\
\text { child }\end{array}$ & $\begin{array}{l}\text { To give a loan to a country that does not } \\
\text { complete its obligations }\end{array}$ \\
\hline To suffer pain & To take the consequences of the crisis \\
\hline To reward good behavior & To offer debt relief \\
\hline Good behavior & Implements the lending conditions \\
\hline
\end{tabular}

The concept of punishment is present in the scenario of the magnanimous parent. In the next excerpt, the European Commission is in the role of the magnanimous parent, forgiving its child (Greece), even trying to help it and letting it live with what it has done to itself: 
Donald Tusk said in a joint media conference with Tsipras: "No one is interested in punishing Greece.

"Our only goal yesterday and today, and also tomorrow, is to help Greece.

"You know that the crisis itself is punitive enough."

Tusk said he was confident a deal was close, saying there is "no political alternative". (www.euronews.com, 04/05/2017)

The same structure used above about the economical crisis in Greece is found in texts about the political crisis in the UK:

The EC President insisted Britain's withdrawal from the bloc must come ahead of any new relationship between the two parties. Yet he said the $\boldsymbol{E} \boldsymbol{U}$ will not seek to punish the UK in the initial stage of the talks. "We will not be punitive. Brexit itself is punitive enough," he said. (www.independent. co.uk, 31/03/2017)

The use of the same metaphor in the two cases leads to the following observation: when a member country starts to behave in a way that EU institutions do not approve, media present this following the same model - misbehaving children their parents should punish. Also, it is evident that with the change of the political situation, there could be a change in the model of presentation and more specifically in the family role a country occupies. For instance, the UK is typically presented as a marriage partner and hence the divorce scenario is exploited. When the country is said to have done things the EU does not very much agree with, it is presented as a disobedient child. That way, a model of equality is substituted with a model of subordination.

The EU children are not always disobedient. The countries which fulfill their commitments are called "good children". However, when used in their own media, this phrase has negative connotation, as in the next excerpt:

Понякога човек има усещането, че Румъния и България са заели позицията на добрите деца в блока - понякога прекалено добри и може би невинаги гледащи своите собствени интереси (www.blitz.bg, 01/01/2017)

One sometimes gets the feeling that Romania and Bulgaria have taken the position of the good children in the bloc - sometimes far too good and maybe not taking care of their own interests. (www.blitz.bg, 01/01/2017)

\subsection{Poor realtives.}

In the British press, however, Eastern countries are called "poor relations" and are presented as a burden for "the family" of the European Union:

EU must pay price to keep Eastern poor relations in the family 
The crisis in Central and Eastern Europe has been triggered by the world's financial turmoil. But the European Union was already set for an unpleasant showdown between its older members and its newer ones. Any recession never mind one as acute as this - would have driven home the point that the east wants more than voters in the west want to pay (www.thetimes.co.uk, 03/03/2009).

The expression "бедните роднини" (poor relatives) is used in Bulgarian press as well. However, while in the British media their poverty is bad for the EU and involves a large "family" expenditure, in Bulgarian media poverty is bad for the people who live in the country:

Оставаме си бедните роднини не само в $\boldsymbol{E C}$, но и в Европа изобщо

Доходите на българите са не просто най-ниските в ЕС, но са пониски дори от тези на гражданите на държави извън Евросъюза, като например Хърватска. (www.budnaera.com, 20/08/2008)

We remain the poor relatives not only in the $\boldsymbol{E U}$, but in the whole Europe

Bulgarians' income are not just the lowest in the EU, they are lower even compared to those of people living in countries outside the Union, such as Croatia. (www. budnaera.com, 20/08/2008)

The expression "poor relative" with its variations (poor cousin, poor relation) is used not only for countries in a bad economic situation, but also for developed countries which are in a relatively worse position in certain aspect, compared to other developed countries.

\section{UK will be 'poor cousin' of European science, Brexit study warns}

Almost £lbn in annual research funding would be thrown into doubt if the UK left the EU, according to a study warning that quitting the bloc could turn Britain into the "poor cousin" of European science.(The Financial Times, 17/05/2016)

\subsection{Stepmother.}

For countries which have aspirations to enter the EU, but have not yet started the talks for admission, the EU is a stepmother. Since they are not yet part of the European family, the Union is not yet their mother, as shown in the next excerpt:

Financial aid has been delivered, but it is dwarfed by the aid and investment flooding in from the Turkish Cypriots' traditional patron state, Turkey. If Turkey is still the motherland, the EU is still a stepmother. In the absence of a big EU presence, the influence of modern Turkey is steadily growing in 
northern Cyprus, with the privatization of businesses and an (unwelcome to many) program of mosque building. (http://carnegieeurope.eu, 03/07/2017)

Another reason for the choice of the expression "stepmother" is the negative connotation that is typically associated with the word. The use of the adverb "still" demonstrates that the situation and the attitude can change with time.

The word "stepmother" is used not only for supranational organization, but also for a single country. When the country government does not take enough care of the country's interests and its citizens' well-being, the country is presented as a stepmother:

\section{България - мащеха за своите безценни билки}

България успява да преработи нищожни количества от билките, които се берат у нас. Едва 5\% от 15000 тона, които се добиват годишно, остават в страната. (www.trud.bg, 20/06/2017)

\section{Bulgaria - a stepmother to its precious herbs}

Bulgaria manages to process insignificant amounts of the herbs that are gathered in the country. Only $5 \%$ of a total annual production of 15000 tons are left in the country. (www.trud.bg, 20/06/2017)

\section{Conclusion.}

The family scenario is widely exploited in both the Bulgarian and the British media. Relations between countries are presented as family relations. The choice of the type of family relation in the source domain depends on the nature of the event that is portrayed in the media. A member state that is about to leave the $\mathrm{EU}$ is presented as a former marriage partner that is in a divorce process with the Union. The EU is portrayed as a parent punishing or helping its children. Member countries who do not comply with the EU directives are presented as misbehaving children and the legal actions against them are called punishment. Countries in an unfavourable economic situation are presented as poor relatives while the attitude of some non-EU members towards the EU is manifested by the use of the concept "stepmother".

The type of family relation can change with a change in the political environment - for instance, a country can be presented as a marriage partner in one text, as a divorcee in another and as a (disobedient) child in a third text.

\section{References:}

Lakoff 1990: Lakoff G. Metaphor and War: The Metaphor System Used to Justify War in the Gulf. - Viet Nam Generation Journal and Newsletter. V3. N3. Viet Nam Generation, Inc. 
Musolff 2006: Musolff A. Metaphor Scenarios in Public Discourse. - Metaphor and Symbol. 21(1). 23-38.

Musolff 2009: Musolff A. Love, Parenthood and Gender in the European Family: The British Perspective. - Europa - Stier und Sternenkranz. Von der Union mit Zeus zum Staatenverbund. Vandenhoeck \& Ruprecht. 536-548.

Ishpekova 2012: Ishpekova R. Policing the Naughty Newbies. Sofia: Unison Art.

\section{Internet sources:}

Longman Dictionary of Contemporary English Online. <www.ldoceonline.com/> [Accessed 15 Sept. 2017]

\section{Excerpted sources:}

www.blitz.bg

www.budnaera.com

http://carnegieeurope.eu

www.cbc.ca/news

www.euronews.com

www.ft.com

www.independent.co.uk

www.thetimes.co.uk

www.trud.bg,

www.politico.eu

http://sbj-bg.eu 